\title{
Visual Representations in Richard Aldington's London (May 1915) and Eros and Psyche
}

\author{
Tzu Yu Allison Lin, Mehmet Çiçek \\ Gaziantep University, Gaziantep, Turkey
}

\begin{abstract}
Through reading Walter Benjamin's critical essay, Surrealism: The Last Snapshot of the European Intelligentsia, the authors of this research would like to trace the key point of Surrealist aesthetics, particularly the juxtapositions of visual objects in the city of London. Richard Aldington's two poems, London (May 1915) and Eros and Psyche, come to depict Surrealist image spheres, as their visual representations in words would show. The dialectical optic of the poet comes to reveal an allegorical synthesis, giving birth to new meanings. The city of London shows the irrational fusion of the opposites, in a way which a Surrealist reading of these two poems is able to construct a critical virtue.
\end{abstract}

Keywords: London, surrealism, object, allegory, love

\section{Introduction}

The aim of this research is not to claim that Richard Aldington should be catagorised as a Surrealist poet; his poems are specifically Surrealist. Rather, in this article, the authors want to show the possibilities of reading two of Aldington's poems: London (May 1915) and Eros and Psyche through a Surrealist perspective. Focusing on visual objects, love and allegory, Aldington's two poems can be read in terms of the way in which images and colours come to form a dream-like cityscape of London.

\section{Object}

A city is a dialectic representation of love. In London, as Allison Lin claims, love can be understood as "a dream-like image", as in "a surreal illusion of love, which stays in the viewer's mind as a poem of colours, representing eternity” (Lin, 2016, p. 1). In Walter Benjamin's Surrealism: The Last Snapshot of the European Intelligentsia, the reader can see that this representation of love comes in several forms, in the Surrealist montage: dream, mémoire involontaire, desire, and visual objects. All elements in a city, no matter the subjective one or the objective one, the inner aspect or the outer aspect, under the form of Surrealist aesthetics, for Benjamin, come to show a collective "humanistic concept of freedom” (Benjamin, 1986, p. 177).

Nevertheless, as J. H. Matthews has pointed out that the English Surrealists "show their close alliance with surrealism in France” (Matthews, 1964, p. 59), just as Breton keeps his admiration to M. G. Lewis and the

Tzu Yu Allison Lin, Ph.D., Assistant Professor, Faculty of Education, Gaziantep University.

Mehmet Çiçek, Ph.D., Professor, Faculty of Education, Gaziantep University. 
English “Gothic novels” (Matthews, 1964, p. 57). In writing, Surrealism can be defined as such, representing "psychic automatism in its pure state, by which one proposes to express—verbally, by means of the written word, or in any other manner - the actual functioning of thought”, as the reader can see in the Manifesto of Surrealism, when André Breton published it in Paris, in 1924 (Woodruff, 2003, p. 191; Matthews, 1975, p. 1).

The free association of visual objects, no matter how striking the image would be, the Surrealist perspective somehow comes to show us a method of artistic and literary creation, in a way which the visible objects can be twisted, juxtaposed, and re-represented, in order to construct an imaginary world of fancy. In poetry, specifically, as Nicholas Calas has observed that this imaginary world of fancy can be revealed, as the poet's "disorderly passion" comes to give a "greater freedom” (Glicksberg, 1949, p. 303) to poetic writings. The disorderly passion is inspired by love, indicating an unconscious desire, in a way which deep emotions are aroused. The visual and the verbal representations of this "bizarre imaginative effect” (Baldick, 2008, p. 324)—in a surreal sense—come to depict a romantic transition between the present and “a remote, primordial past” (Glicksberg, 1949, p. 303), as the readers can see in Aldington's two poems.

Indeed, the psychological and intuitive motifs of Surrealism come to show the reader a way in which the oppressed can be released, as Surrealist aesthetics can be understood as a form of representing "an absolute reality”- “a surreality” (Wolin, 1997, p. 97). The juxtaposition of visual objects is the key for the dialectical moment to happen, embracing each visual object even when it is out of its own original cultural context, as the new meaning emerges. In this respect, in semiotic terms, a visual object contents not only its "informational" (Barthes, 1997, p. 52) meaning - on the first level. Rather, the very visual object serves as a symbol, on the second level, as "the signifier" (Barthes, 1997, p. 53). It should have a new meaning to be read, in a way which it is not what it is signified, as Barthes called it, “a poetical grasp”—on the third level (Barthes, 1997, p. 53).

\section{Love}

In Richard Aldington's London poem, Eros and Psyche, the reader can see that the statue of Eros and Psyche is a good example, which comes to show our "poetical grasp”, in Barthes's term. It is worth it to read the whole poem:

\section{Eros and Psyche}

In an old dull yard near Camden Town,

Which echoes with the rattle of cars and 'buses

And freight-trains, puffing steam and smoke and dirt

To the steaming sooty sky-

There stands an old and grimy statue,

A statue of Psyche and her lover, Eros.

A little nearer Camden Town,

In a square of ugly sordid shops,

Is another statue, facing the Tube,

Staring with heavy purposeless glare

At the red and white shining tiles-

A tall stone statue of Cobden.

And though no one ever pauses to see

What hero it is that faces the Tube, 
I can understand very well indeed

That England must honour its national heroes, Must honour the hero of Free Trade-

Or was it the Corn Laws?-

That I can understand.

But what I shall never understand

Is the little group in the dingy yard

Under the dingier sky,

The Eros and Psyche-

Surrounded with pots and terra-cotta busts

And urns and broken pillars-

Eros, naked, with his wings stretched out Just lighting down to kiss her on the lips.

What are they doing here in Camden Town In the midst of all this clamour and filth? They, who should stand in a sun-lit room Hung with deep purple, painted with gods, Paved with dark porphyry,

Stand for ever embraced

By the side of a rustling fountain

Over a marble basin

Carved with leopards and grapes and young men dancing;

Or in a garden leaning above Corinth,

Under the ilexes and the cypresses,

Very white against a very blue sky;

Or growing hoary, if they must grow old,

With lichens and softly creeping moss:

What are they doing here in Camden Town?

And who has brought their naked beauty

And their young fresh lust to Camden Town,

Which settled long ago to toil and sweat and filth,

Forgetting - to the greater glory of Free Trade-

Young beauty and young love and youthful flesh?

Slowly the rain settles down on them,

Slowly the soot eats into them,

Slowly the stone grows greyer and dirtier,

Till in spite of his spreading wings

Her eyes have a rim of soot

Half an inch deep,

And his wings, the tall god's wings,

That should be red and silver

Are ocherous brown.

And I peer from a 'bus-top

As we splash through the grease and puddles, And I glimpse them, huddled against the wall, Half-hidden under a freight-train's smoke, And I see the limbs that a Greek slave cut In some old Italian town, 
I see them growing older

And sadder

And greyer. (Ford, 2012, pp. 525-526)

In this poem, the dialectical optic of the poet comes to reveal a Surrealist effect, as the montage of different visual objects would show: old statue verses the shinning one, England national hero verses Greek mythology, the honourable verses the dingy, the glory Free Trade verses the filthy London reality. The statue of Eros and Psyche represents the "punctum" (Barthes, 1993, p. 47), in a way which a visual object comes to disturb the critics, to make him and her "dream” (Barthes, 1993, p. 49). The statue itself, among other visual objects in London, as the viewer comes to "peer" (Ford, 2012, p. 526) from the top of a double-decker London bus, is that special "something" (Barthes, 1993, p. 49), which has a Greek origin—a past which comes to refuse all signs of the viewer's cultural present, as London Camden Town can be represented by an "old dull yard”, with some "ugly sordid shops" in it, near a Tube station.

As Barthes claims, in his Camera Lucida, the "studium is ultimately always coded" (Barthes, 1993, p. 51). The statue of Eros and Psyche also has its own original cultural meaning, in its own context. And yet, in London, the statue can be read as a Surrealist appeal, as Eros and Psyche should be

[b]y the side of a rustling fountain

Over a marble basin

Carved with leopards and grapes and young men dancing (Ford, 2012, p. 526)

Eros and Psyche should be in its own cultural context, just like the "tall stone statue of Cobden" (Ford, 2012, p. 525), in its own cultural context in London, as a national hero-although "no one ever pauses to see” (Ford, 2012, p. 525).

And yet, in the poem, there are two images come to suggest the original meaning of the statue which are deconstructed by the same question, asked twice by the viewer:

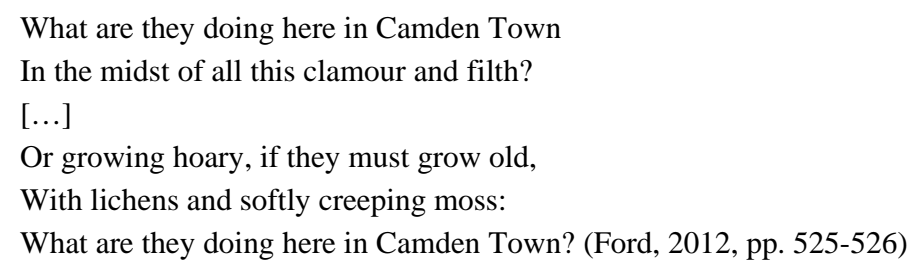

"They"-Eros and Psyche, because of these two questions, immediately, become the "punctum" in Barthes's term. They should be in their own cultural context, as in the viewer's dream-like image. Eros and Psyche "should stand in a sun-lit room/[...]/Stand for ever embraced" (Ford, 2012, p. 525). However, in London Camden Town, they are the "punctum", because they are not "[b]y the side of a rustling fountain/Over a marble basin/Carved with leopards and grapes and young men dancing” (Ford, 2012, p. 526). In London Camden Town, their young love and young flesh, for the viewer, are like the "essence (of a wound)" (Barthes, 1993, p. 49), teasing the viewer's feeling.

As the critical viewer sees in Camden Town, among all other visual objects, the statue of Eros and Psyche reminds the viewer the "sweat and filth" of London's reality. It is a cityscape of commodity, Free Trade, and the national hero’s "tall stone statue”- standing there, in red and white, "shinning” (Ford, 2012, p. 525). In reality, 
the viewer can only see the statue of Eros and Psyche shows, as a part of Camden Town, covered by "a rim of soot", and eaten "softly" by the "creeping moss" (Ford, 2012, p. 526). The statue of Eros and Psyche, in London, is ironically freed from its past, its once-upon-a-time, as we come to understand Benjamin's concept of "the historical object-world” (Steinberg, 1996, p. 92). Aldington's dialectical optic is able to see the statue of Eros and Psyche, once, the "heroic" object, juxtaposing among the "ordinary" (Scott, 2007, p. 131) London visual objects—such as shops and commodities. The statue, again, implies that love in London is somehow visually represented as some erotica, which is located within the conscious materialist practice.

\section{Allegory}

In the poem, the Surrealist status of the statue, Eros and Psyche, comes to reveal the reality of "sweat and filth" (Ford, 2012, p. 526) of London Camden Town. "Free Trade”, modernization, urbanization—all visual objects of the social milieu come to indicate the degeneration of love-from Greek mythology to "Greek slave" (Ford, 2012, p. 526), from the aura of love and the beauty of a work of art, as the statue itself once represented, to a skin-deep kind of "young fresh lust" and "youthful flesh" (Ford, 2012, p. 526). The young lust and young flesh can be visualized as in Walter Sickert's sketch, Study for L'Affaire de Camden Town (Robins, 1909, p. 67), as the woman's naked body under the gaze would show.

The "Greek slave cut" that the poet sees on the "limbs" (Ford, 2012, p. 526), comes to remind the viewer the statues of a pure commodity of a female body, as Jean Léon Gérôme’s Roman Slave Market (Higonnet, 1884, p. 407) would show. The lover's "naked beauty" becomes "young flesh lust” (Ford, 2012, p. 526) in London Camden Town, indicating a "profane illumination" (Woodruff, 2003, p. 198) of the city. The word "lust", in the poem, reveals a pure sexual desire. As in Breton's Paris, in his novel Nadja, one can see that "man and woman indifferently continue making love” (quoted in Woodruff, 2003, p. 198). Lust, in a sexual way, is an attitude of being indifference, as the female body is commodified, which is exchangeable, in the urban market.

If we read the statue of Eros and Psyche as a visual representation of love, even it is a sad one, as the ending of the poem suggests, somehow, in the context of London Camden Town, it has an allegorical meaning. As the viewer's gaze shows, the passion in the city is more visual rather than verbal. Through reading Baudelaire, Benjamin also reveals the way of seeing salvation and redemption via the ruination of the poetic object. In Aldington's poem, as the reader can see that the statue — the poetic object itself-is "slowly" (Ford, 2012, p. 526) eaten by the rain and the soot, becoming dirtier, in a colour of "ocherous brown" (Ford, 2012, p. 526). The dialectical optic transforms the poet's London into a dialectical moment, in a way which the spatial and the temporal gaps are gone, as Eros’s “tall god's wings” lose their “red and silver” colour, Psyche’s eyes "have a rim of soot” (Ford, 2012, p. 526). All visual objects and their meanings are crumbled in this dream-like image sphere, as they are commodified, and getting weaker. London, at this point, is "a site overlaid with myth and peopled with unrecognized sphinxes” in Aragon's words (Abbas, 1989, p. 48). Eros and Psyche can be read as the London experience of Benjamin's phantasmagoria. The overwhelming juxtaposition of the modern and the premodern is sad and grey, because one can see the disappearing aura of a work of art is the image of the shock. Somehow, the ugly shops are the visual representations of the new and the now-indicating the modern myth of progress.

The question of "What are they doing here in Camden Town?" somehow represents the tension of modernity in the city, in a way which the nowness of the Tube station and the ugliness of the shops come together with the 
ancient Eros and Psyche statue, creating a kind of shock. As the bus passing, the visual image of the statue becomes blur, "[h]alf-hidden under a freight-train’s smoke" (Ford, 2012, p. 526). At this very moment, the viewer seems to have a dream-like image, representing the visual form of the statue. We are not sure whether this image is a dream, or an illusion, or a memory, as the viewer sees "the limbs that a Greek slave cut/In some old Italian town”-Eros and Psyche seem to become "older”, "sadder” and "greyer” (Ford, 2012, p. 526). Here, the salvation and redemption of the visual image seem to come from a dialectical moment of revelation, as the viewer's present is engaged to an illusionary past, as the statue of Eros and Psyche loses its ancient mythological meaning. They are, indeed, just like a normal human couple who share a common human fatetogether, and to die.

In the poem London (May 1915), the reader can see that the city of London is visually represented as the dialectical moment of dream and allegory, when day comes to synthesize with night, "dingy” with "white”, the ancient comes to inspire the present, when "ruins" come to exist with the myth of urbanization-mess production, industrialization, and “chimneys” (Ford, 2012, p. 523). Through Surrealist visual representations, love comes to transit the past and the present, bringing beauty and ecstacy. Now we read the poem:

\section{London (May, 1915)}

Glittering leaves

Dance in a squall;

Behind them bleak immoveable clouds.

A church spire

Holds up a little brass cock

To peck at the blue wheat fields.

Roofs, conical spires, tapering chimneys, Livid with sunlight, lace the horizon.

A pear-tree, a broken white pyramid

In a dingy garden, troubles me

With ecstasy.

At night, the moon, a pregnant woman,

Walks cautiously over the slippery heavens

And I am tormented,

Obsessed,

Among all this beauty,

With a vision of ruins,

Of walls crumbling into clay. (Ford, 2012, p. 523)

The Surrealist perspective reveals the dialectical optic, in a way which the reality of a city is viewed as a dream, a world of "monumental ruins" (Abbas, 1989, p. 48). The city of London represents the dialectical moment of dream and allegory, when the poet’s visual ecstacy comes to "trouble" him (Ford, 2012, p. 523). In Benjamin's Surrealism essay, the reader can see that the intensity of the sensual experience towards "a mystical beloved" (Benjamin, 1986, p. 181) somehow becomes the very energy of revolution, in a "world of things" (Benjamin, 1986, p. 182), in terms of Surrealist visual and verbal representations. The "broken write pyramid" in 
"a dingy garden” in the day time ("[l[ivid with sunlight”) comes to juxtapose with the image of the night- - "the moon" and the walk of "a pregnant woman" (Ford, 2012, p. 523). In the Surrealist aesthetic sense, the walk of the pregnant woman in the night time indicates a desire of creation, coming from the unconscious, in the darkness, in the dream. The vision of heaven, representing in London, at this dialectical moment, has an allegorical meaning of beauty and love, even it is found in "ruins/Of walls crumbling into clay" (Ford, 2012, p. 523). The calling and the envision of a "rebirth" (Buck-Morss, 1999, p. 255) of the ancient ruins, on the dream level, reveal a subversive creative power over the "systematic rationalization” (Buck-Morss, 1999, p. 254) of the industrial city of London.

\section{Conclusion}

In the London poem, the viewer's “allegorical gaze” (Gilloch, 1997, p. 137) sees meanings out of the white pyramid in the garden, and a pregnant woman walking in the night. In Eros and Psyche also, the "I" has a view, looking out from a London bus, which frames the moment of the visual. As the aesthetics of Surrealism would suggest, the juxtaposition of different visual objects, such as the "tall stone statue" of the national hero on the street of London, together with shops and the Tube, comes to show the subversive meaning of the out-of-context statue: Psyche and her lover, Eros. The statue of Eros and Psyche in Eros and Psyche, together with the white pyramid in London, come to represent the punctum, in Roland Barthes's term, in a way which they both deconstruct the existing cityscape of London-“dingy”, “clamour”, “filth”, and "lust”. The viewer, with his allegorical optic, perceives the dialectical moment, as in a snapshot, which comes to synthesize the opposites in the world of visual objects.

\section{References}

Abbas, A. (1989). On fascination: Walter Benjamin’s Images. New German Critique, 48, 43-62.

Baldick, C. (2008). Oxford dictionary of literary terms. Oxford: Oxford University Press.

Barthes, R. (1993). Camera Lucida. London: Vintage.

Barthes, R. (1997). The third meaning. Image music text (S. Heath, Trans.). New York: Hill and Wang.

Benjamin, W. (1986). Surrealism: The last snapshot of the European intelligentsia. Reflections (E. Jephcott, Trans.). New York: Schocken.

Ford, M. (Ed.). (2012). London: A history in verse. Cambridge, MA: Harvard University Press.

Gilloch, G. (1997). Myth and metropolis: Walter Benjamin and the city. Cambridge: Polity.

Glicksberg, C. I. (1949). The poetry of surrealism. Prairie Schooner, 23(3), 302-313.

Higonnet, P., \& Margaret, A. (1984). Façades: Walter Benjamin’s Paris. Critical Inquiry, 10(3), 391-419.

Lin, T. Y. A. (2016). London poetics. Taipei: Showwe.

Matthews, J. H. (1964). Surrealism and England. Comparative Literature Studies, 1(1), 55-72.

Matthews, J. H. (1975). Fifty years later: The manifesto of surrealism. Twentieth Century Literature, 21(1), 1-9.

Buck-Morss, S. (1999). The dialectics of seeing: Walter Benjamin and the arcade project. Cambridge, MA: MIT.

Robins, A. G. (1996). Walter sickert: Drawings. Hants: Scolar.

Scott, C. (2007). Street photography: The appropriateness of language and an appropriate language. Street photography: From Atget to Cartier-Bresson. London: I. B. Tauris.

Steinberg, M. P. (Ed.). (1996). Walter Benjamin and the demands of history. Ithaca: Cornell University Press.

Wolin, R. (1997). Benjamin, Adorno, surrealism. In T. Huhn and L. Zuidervaart (Eds.), The semblance of subjectivity. Cambridge, MA: MIT.

Woodruff, A. (2003). The shape of a city: Recollection in Benjamin's A Berlin Chronicle and Breton's Nadja. Journal of Narrative Theory, 33(2), 184-206. 